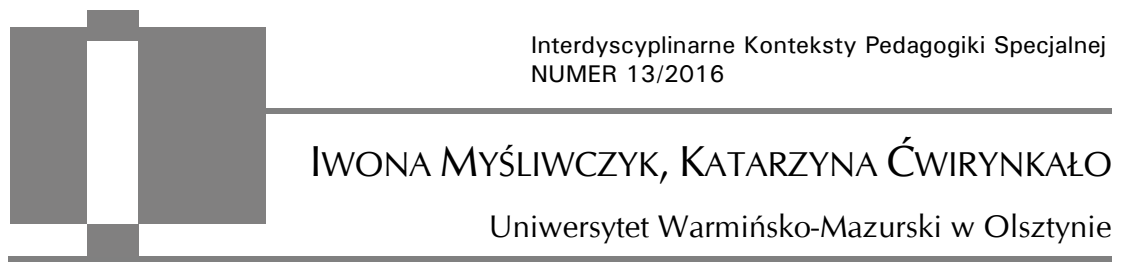

\title{
Interpretowanie i konstruowanie swojej dorosłości z perspektywy osób niepełnosprawnych
}

\begin{abstract}
[...] to my, „petnosprawna” większość, dyskutujemy im ich społeczna tożsamość,

a oni sa jedynie przedmiotem naszego definiowania. Stąd wynika społeczna ocena osób niepetnosprawnych jako biednych, smutnych i nieszczęśliwych.
\end{abstract}

E. Zakrzewska-Manterys

\begin{abstract}
Iwona Myśliwczyk, Katarzyna Ćwirynkało, Interpretowanie i konstruowanie swojej dorostości z perspektywy osób niepetnosprawnych [Interpreting and constructing one's adulthood from the perspective of the persons with disabilities]. Interdyscyplinarne Konteksty Pedagogiki Specjalnej, nr 13, Poznań 2016. Pp. 87-101. Adam Mickiewicz University Press. ISSN 2300-391X

Research on the adulthood of people with disabilities is still scarce. In the article the results of a qualitative research project involving the use of three individual, indepth semistructured interviews and a narrative analysis approach are presented. The authors show the everyday life of adults with disabilities, which is not thrown into the scheme, because it distances itself from stereotypes. Positive self-perception of these people - depicted in narratives - is visible in their perception of adulthood, which is implemented in the same way as in the case of the able-bodied, so that's the adulthood with prospects of self-realization. Difficulties implied by disability become insignificant.
\end{abstract}

KEY WORDS: adulthood, otherness, barriers, perspectives 


\section{Inny w społeczeństwie}

Swoje rozważania chciałybyśmy rozpocząć od przytoczenia słów Zygmunta Baumana, który podkreśla, iż Obcy ponowocześni za ogólną zgoda mają zostać stałym elementem krajobrazu, a ich obecność nie jest już dziś problemem. Chodzi bowiem o to, żeby nauczyć się żyć z innością na co dzień, a nie - jak dotychczas - dążyć do jej wyeliminowania ${ }^{1}$. Przesłanie Baumana byłoby fenomenalnym włączeniem niepełnosprawnych $\mathrm{w}$ społeczeństwo, ale praktyka pokazuje, że udział grupy osób z niepełnosprawnością dotyczy tylko niektórych płaszczyzn społecznego istnienia, niekiedy bywa marginalny. Mimo iż na przestrzeni lat postrzeganie człowieka $\mathrm{z}$ niepełnosprawnością zdecydowanie zmieniło się na lepsze ${ }^{2}$, to nadal człowiek ten określany jest mianem Inny czy Obcy.

W literaturze przedmiotu dużo miejsca poświęca się społecznemu funkcjonowaniu osób $\mathrm{z}$ niepełnosprawnościami, ich udziałowi w sferze życia rodzinnego, edukacyjnego i zawodowego. Niestety, idee integracji czy normalizacji pozostają na etapie tolerancji tylko do momentu, kiedy nie musimy ustąpić im miejsca $\mathrm{w}$ przestrzeni społecznej. Rodzi się więc pytanie, dlaczego tak trudno współistnieć pełnosprawnym z niepełnosprawnymi, dlaczego funkcjonowanie pełnosprawnych implikuje szereg barier w życiu niepełnosprawnych, dlaczego swoją postawą wytyczamy ścieżki, którymi osoby z niepełnosprawnością za naszą zgodą mogą podążać i dlaczego pełnosprawni łamią prawa człowieka niepełnosprawnego, nie pozwalając mu wywiązywać się z różnych ról społecznych? Być może wszystko wynika z faktu - jak czytamy u Amadeusza Krause - że nie dajemy przyzwolenia osobom niepełnosprawnym na zachowanie „odmienności”, którą zostały dotknięte. Dopiero zmiana schematu kulturowego łagodzi ową "odmienność” i prze-

${ }^{1}$ Z. Bauman, Ponowoczesność jako źródło cierpień, Wydawnictwo Sic!, Warszawa 2000, s. 59.

2 A. Ostrowska, Niepetnosprawni w społeczeństwie 1993-2013, IFiS PAN, Warszawa 2015. 
staje budzić zastrzeżenia ${ }^{3}$. Do tego momentu funkcjonują stereotypy, które zniekształcają obraz życia osób z niepełnosprawnością, czyli „tzw. publiczna tożsamość jednostki zostaje przekształcona w coś, co jest uważane za gorsze w specyficznej konfiguracji typów społecznych"4.

Iwona Chrzanowska, powołując się na Tadeusza Mądrzyckiego, pisze, iż stereotyp „rozumiany jest najczęściej jako przekonanie, proste zjawisko poznawcze, szczególnego rodzaju uogólnienie, szczególne, gdyż zbyt ogólne i zbytnio uproszczone, stąd błędne w konkluzji"5. U Franciszka Wojciechowskiego czytamy, iż stereotypy „jako umysłowe reprezentacje świata wpływają na to, jakich informacji dotyczących różnych grup społecznych człowiek poszukuje [...]. [...] znaczenie stereotypów w podejściu otoczenia społecznego do jednostek określanych jako inne, nietypowe wydaje się szczególne, a konsekwencje tych stereotypów dla osób naznaczonych mogą być wyjątkowo bolesne"6. Następstwa te wynikają z "obowiązywalności” i sztywności stereotypu. Zmiana takiego stanu rzeczy może nastąpić dopiero w wyniku „rozmiękczania” tych wszystkich wewnętrznych niespójności i wieloznaczności interpretacji, które zdefiniowały niewłaściwie życie osób niepełnosprawnych 7 .

To, jaką przestrzeń pozostawiamy osobom z niepełnosprawnościami w społeczeństwie, skutkuje przyznanym przez pełnospraw-

${ }^{3}$ A. Krause, Człowiek niepetnosprawny wobec przeobrażeń społecznych, Oficyna Wydawnicza „Impuls”, Kraków 2004, s. 99.

${ }^{4} \mathrm{~F}$. Wojciechowski, Stereotypy i uprzedzenia a proces normalizacji życia osób z niepetnosprawnością, [w:] Konteksty teoretyczne, red. E. Górniewicz, A. Krause, Wydawnictwo Uniwersytetu Warmińsko-Mazurskiego, Olsztyn 2003, s. 143.

${ }^{5}$ I. Chrzanowska, Pedagogika specjalna. Od tradycji do wspótczesności, Oficyna Wydawnicza „Impuls”, Kraków 2015, s. 92.

${ }^{6} \mathrm{~F}$. Wojciechowski, Stereotypy i uprzedzenia a proces normalizacji życia osób z niepetnosprawnościa, [w:] Konteksty teoretyczne, red. E. Górniewicz, A. Krause, Wydawnictwo Uniwersytetu Warmińsko-Mazurskiego, Olsztyn 2003, s. 146.

${ }^{7}$ E. Zakrzewska-Manterys, Dziecko upośledzone - nieuchronność stereotypów, [w:] Niepetnosprawność intelektualna a style życia, red. A. Gustavsson, J. Tøssebro, E. Zakrzewska-Manterys, Wydawnictwo PAN, Warszawa 2003, s. 117. 
nych prawem do posiadania przez te osoby tożsamości. Inny konstruowany jest na podstawie własnych doświadczeń pełnosprawnego, relacji i wiedzy, która nie zawsze jest prawdziwa ${ }^{8}$. Oznacza to, jak podkreśla Krystyna Rzedzicka, że ten wizerunek „,konstruowany jest $\mathrm{w}$ opozycji do pojęcia normalności. Ich obraz jest ustalony, wiadomy i zwykle kojarzy się z defektami, uszkodzeniami, deficytami, ograniczeniami, a $\mathrm{w}$ konsekwencji $\mathrm{z}$ niesamodzielnością i koniecznością udzielania im pomocy" ${ }^{\prime 9}$. Te i inne czynniki skutkują negatywnym spostrzeganiem osób niepełnosprawnych, co zdecydowanie pogarsza ich sytuacje. Dodatkowym elementem składającym się na to niekorzystne położenie tej grupy osób jest to, że osoby z niepełnosprawnością intelektualną nie zawsze mogą „wypowiadać się w swoim imieniu, wtedy gdy możliwe staje się zabranie głosu $\mathrm{w}$ walce o swoje prawa, przywileje, przeciwko dyskryminacji o różnych obliczach"10.

Praktyki dyskredytujące osoby niepełnosprawne w społecznej egzystencji przyczyniły się do wprowadzenia terminów: „napiętnowani”, czyli „nosiciele piętna” i „normalsi”. Erving Goffman poczynił rozważania nad funkcjonowaniem tych dwóch grup w społeczeństwie i wyraził swoje zaniepokojenie. $W$ bezpośredniej relacji nosiciela piętna i normalsa "pojawia się [...] samoświadomość oraz świadomość innego, co znajduje wyraz w patologii interakcji - zakłopotaniu"11. Owo zakłopotanie występuje, ponieważ następuje uświadomienie, że ten Inny nie przystaje do wzorca, który został stworzony przez grupę osób pełnosprawnych. Wówczas nadaje się mu stygmat "Gorszego Innego"12, który nie jest uznawany za "peł-

${ }^{8}$ A. Krause, op. cit., s. 206.

${ }^{9}$ K. Rzedzicka, Inny w edukacji, [w:] Dylematy pedagogiki specjalnej, red. A. Rakowska, J. Baran, Wydawnictwo Naukowe Akademii Pedagogicznej, Kraków 2000, s. 27.

${ }^{10}$ B. Cytowska, Trudne drogi adaptacji. Watki emancypacyjne w analizie sytuacji dorosłych osób z niepetnosprawnościa intelektualna we wspótczesnym społeczeństwie polskim, Oficyna Wydawnicza „Impuls”, Kraków 2012, s. 117.

${ }^{11}$ E. Goffman, Piętno. Rozważania o zranionej tożsamości, Gdańskie Wydawnictwo Pedagogiczne, Gdańsk 2007, s. 51.

${ }^{12}$ E. Czykwin, Stygmat społeczny, Wydawnictwo PWN, Warszawa 2008. 
nego" człowieka. To umniejszenie człowieczeństwu Innego i jego godności skutkuje rozlicznymi praktykami wykluczającymi, przez co zmniejszają się jego życiowe szanse ${ }^{13}$.

Reasumując powyższe rozważania, warto wrócić do słów cytowanego już Baumana, który pisze: „[...] jak długo zbiorowym i indywidualnym działaniem kieruje potrzeba ładu rozumianego jako nieobecność wieloznaczności, tak długo będzie mu towarzyszyła nietolerancja - nawet jeśli kryje się ona wstydliwie pod maską dobrodusznego przyzwolenia na odmienność"14. Owa nietolerancja implikuje szereg barier dla osób z niepełnosprawnościami, które ograniczają lub odbierają im prawo do „normalnego" życia.

\section{Zastosowana metodologia}

Celem artykułu jest zaprezentowanie wyników badań dotyczących interpretowania i konstruowania swojego życia przez dorosłe osoby z niepełnosprawnością. Interesowało nas, jak ta grupa osób doświadcza dorosłości i jak ją interpretuje, jakiego znaczenia nadaje różnym aspektom swojego dorosłego życia, w jaki sposób konstruuje swoją teraźniejszość i przyszłość.

Podjęte badania zostały osadzone $\mathrm{w}$ nurcie badań interpretatywnych. Podejście to zostało celowo wybrane, ponieważ celem było znalezienie we fragmentach rzeczywistości prezentowanych przez dorosłych niepełnosprawnych, odpowiedzi na pytania, które były dla nas istotne. Zastosowanie jakościowej orientacji badawczej pozwala na

analizowanie przeżyć związanych z doświadczaniem niepełnosprawności jako elementu życiowej codzienności, procesów i mechanizmów radzenia sobie z różnymi ograniczeniami i trudnościami, czy sposobów rozumienia, interpretowania i nadawania znaczeń rozmaitym

${ }^{13}$ A. Woynarowska, Niepetnosprawność intelektualna w publicznym i prywatnym dyskursie, Oficyna Wydawnicza „Impuls”, Kraków 2010, s. 32.

${ }^{14} \mathrm{Z}$. Bauman, Wieloznaczność nowoczesna, nowoczesność wieloznaczna, Wydawnictwo Naukowe PWN, Warszawa 1995, s. 266. 
zjawiskom, zdarzeniom i sytuacjom kształtującym zarówno indywidualny, jak i społeczny wymiar funkcjonowania z niepełnosprawnością ${ }^{15}$.

Inspiracją $w$ toku badań były więc trzy perspektywy: fenomenologia, hermeneutyka i interakcjonizm symboliczny.

Celem naszych badań była rekonstrukcja opowieści i dotarcie do subiektywnych znaczeń, jakie nadają dorośli z niepełnosprawnością fizyczną swojej dorosłości, która „naznaczona” jest stereotypowym myśleniem, ale też takiej dorosłości, która $\mathrm{w}$ odbiorze ich samych ma szanse i powodzenie na normalność. Przedmiotem stały się subiektywne sensy, intencje i interpretacje nadawane przez dorosłych niepełnosprawnych dorosłości i wynikającej z niej barier, ale i możliwości. Badałyśmy więc, jak dorosłe osoby o niepełnej sprawności, poprzez swoje mówienie, doświadczają dorosłości i jak ją konstruują.

Przyjęcie perspektywy interpretatywnej dla potrzeb artykułu umożliwiło zastosowanie metody biograficznej. Badania polegały na próbie zrozumienia znaczeń i sensów nadawanych przez dorosłych niepełnosprawnych fizycznie własnemu doświadczaniu, które konstruuje ich życie. Poprzez swoje narracje badani ukazali swój sposób doświadczania i interpretowania doświadczanej przez nich dorosłości. Zastosowanie metody biograficznej implikowało wykorzystanie analizy narracji. Narracja oparta na historiach ludzi - podkreśla Dorota Klus-Stańska - jest „jednym ze sposobów rozumienia świata przez ludzi”. Autorka zaznacza, że narracja jest ",sposobem naturalnym i koniecznym dla zrozumienia życia"16. Wywiady narracyjne zostały przeprowadzone $\mathrm{z}$ dorosłymi $\mathrm{z}$ niepełnosprawnością fizyczną, którzy mieszkają ze swoimi rodzicami. Badane osoby to:

Anna, lat 23, niepełnosprawność ruchowa - dziecięce porażenie mózgowe, stopień znaczny, studentka III roku studiów zaocznych, kierunek: Pedagogika specjalna

15 J. Rzeźnicka-Krupa, Niepetnosprawność i świat społeczny. Szkice metodologiczne, Oficyna Wydawnicza „Impuls”, Kraków 2011, s. 197.

16 D. Klus-Stańska, Narracja w badaniu i ksztatceniu nauczycieli, „Forum Oświatowe" 2002, s. 111. 
Katarzyna, lat 20, rozszczep kręgosłupa, studentka I roku studiów dziennych, kierunek: Pedagogika specjalna

Piotr, lat 25, czterokończynowe porażenie mózgowe, student I roku studiów dziennych, kierunek: Pedagogika specjalna

\section{Analiza materiału empirycznego}

Funkcjonowanie osób z niepełnosprawnością zależne jest nie tylko od jej rodzaju i stopnia, ale także od społecznego postrzegania przez pełnosprawnych. To pełnosprawni wytyczają drogi, którymi mogą podążać niepełnosprawni i to oni wyznaczają przestrzeń dla osób o niepełnej sprawności, generując z reguły bariery i ograniczenia. Otoczenie społeczne lepiej postrzega osoby z niepełnosprawnością fizyczną niż osoby dotknięte innymi niepełnosprawnościami, jak np. niepełnosprawność intelektualna. Ważne jest także, jak sami niepełnosprawni podchodzą do swojej „inności” i na ile są zdeterminowani, aby funkcjonować „normalnie” w przestrzeni społecznej.

Każda z opowieści jest wyjątkowa i odsłania wachlarz osobistych znaczeń, symboli, interpretacji, rozwiązań i oczekiwań. Narratorzy, opowiadając swoje historie, konstruują swoją "prawdę" o rzeczywistości, której doświadczają u progu dorosłości. Opowieści rozmówców można podzielić na kilka wątków tematycznych, jak: akceptacja siebie jako osoby niepełnosprawnej, łamanie stereotypów, znaczenie barier, definiowanie dorosłości, perspektywa przyszłości.

Analiza narracji ukazuje osoby silne i gotowe na to, aby podjąć trud normalizowania swojego życia. Badani są świadomi swojej niepełnosprawności, ale akceptują siebie i nie traktują swojej niepełnosprawności jako przeszkody w dążeniu do dorosłości:

„No, jakby mam świadomość że jestem niepełnosprawna ale zaakceptowałam to i staram się być aktywna i dążyć do swojej sprawności najbardziej jak tylko mogę i cieszyć się życiem" (Katarzyna). 
„Robię wszystko co mogę, żeby, żeby po prostu być w tym świecie jako osoba..., ja nie myślę o sobie $\mathrm{w}$ ramach niepełnosprawności, oczywiście akceptuję swoją niepełnosprawność i tak dalej, ale dążę do czegoś więcej niż tylko jakby siedzenie na wózku jakby użalanie się nad sobą, bo wiem, że są tacy ludzie niepełnosprawni, że narzekają że ich życie jest do niczego. Staram się to przełamywać [...]" (Piotr).

To pozytywne nastawienie do świata, ludzi ale przede wszystkim siebie, skutkuje brakiem zgody na funkcjonowanie stereotypów na temat niepełnosprawnych. Narratorzy nadają temu wielkie znaczenie i swoją postawą oraz działaniem przełamują panujące sądy. Za przykład posłużyć może wypowiedź Anny:

"Ja myślę, [...] że one są, ja po prostu w większości stereotypów to nie zgadzam się z nimi i chyba to, że jestem tu gdzie jestem pokazuje, że one nie są aktualne" (Anna).

Pokonując różne etapy w swoim życiu, badani przyjmują postawę otwartą do ludzi i wychodzą do nich naprzeciw. Będąc na etapie studiów, burzą $\mathrm{w}$ ten sposób panujące na temat niepełnosprawnych fizycznie opinie:

„Dla mnie samej to nie ma takich stereotypów. [...] ja myślę, że to jest takie stygmatyzowanie tych osób, że np. niepełnosprawny nie może pracować albo uczyć się" (Anna).

"Stereotypy są $[\ldots]$ no np. że osoby niepełnosprawne nie są mądre, że nie mogą daleko zajść albo że uchodzą za osoby wycofane takie, którymi się trzeba opiekować, które nie są samodzielne [...] tylko, że gdyby tak było, to nie byłabym na studiach tylko w domu" (Katarzyna).

Oprócz stereotypów w społecznym i kulturowym przekazie funkcjonują bariery, które w narracji naszych rozmówców nabierają małego znaczenia, bo w większości jest tu mowa o barierach architektonicznych: 
„[...] głównie to są architektoniczne, bo czasami jak jeżdżę na wózku, [...] np. jak z krawężnika sama nie mogę zjechać, to muszę prosić o pomoc kogoś [...]. [...] Te bariery mają dla mnie znaczy małe znaczenie" (Anna).

„Architektoniczne bariery utrudniają moje funkcjonowanie, ale tu np. na studiach koledzy mi tak pomagają, że ja ich prawie nie odczuwam" (Piotr).

Poza barierami architektonicznymi w opowieściach narratorów uwypuklają się także te wynikające z postaw, mentalności i doświadczenia osób sprawnych. Nasi rozmówcy nadają im niewielkie znaczenie, ponieważ mają poczucie własnej wartości, która konstruuje ich tożsamość i pozwala budować prawidłowe relacje z ludźmi, dla których niepełnosprawność nie stanowi problemu:

"Ja myślę, ja po prostu się przyzwyczaiłam, że na świecie są po prostu różni ludzie [...], ale teraz to ja potrafię powiedzieć takim ludziom, że jestem szczęśliwa, że tak żyję i że dzięki Bogu jest dobrze" (Anna).

"Ja się staram obracać w takim środowisku, które mnie akceptuje, a jeśli ktoś mnie nie akceptuje, to po prostu nie zadaję się z takimi osobami i po prostu mam grupkę swoich przyjaciół, znajomych, którzy mi wystarczają" (Katarzyna).

Warte podkreślenia jest to, że badani starają się sami być aktywnymi podmiotami w nawiązywaniu relacji z innymi i przełamują barier wynikających z niewiedzy na temat niepełnosprawnych:

„To nie tylko takie techniczne rzeczy, ale nie wiem, jeżeli chodzi o wychodzenie do ludzi czy kontakty z ludźmi staram się raczej wychodzić jako pierwszy, zacząć jakąś rozmowę lub no ten kontakt, bo zdaję sobie sprawę, że ludzie mogą mieć te ograniczenie w kontakcie z osobą niepełnosprawną. [...] Żyjemy w społeczeństwie i dużo większą wagę przywiązuję do tego, żeby po prostu dogadać się z ludźmi, więc te bariery architektoniczne nie mają aż takiego znaczenia" (Piotr). 
Pozytywne nastawienie do otaczającej rzeczywistości i jej realna ocena powodują, że nasi rozmówcy interpretują dorosłość bardzo naturalnie, a więc jako ukończenie studiów, podjęcie pracy, założenie rodziny, ale także samodzielność, dojrzałość i niezależność w podejmowaniu decyzji czy warunkach bytowych. Sami jeszcze nie czują się dorośli:

„Dla manie dorosłość to znaczy po prostu, znaczy trudno mi $\mathrm{w}$ tej chwili powiedzieć, bo ja nie rozpoczęłam samodzielnego życia, bo mieszkam z mamą. Według mnie dorosłość to jest przede wszystkim to, że się skończy 18 lat, jak się jest niepełnosprawnym, to można samemu decyzje podejmować, pracować, założyć rodzinę. Ja myślę, że byłabym dobrą żoną i matką. Jestem już dojrzała" (Anna).

„Dorosłość to dążenie do samodzielności, do spełnienia marzeń, do podjęcia pracy, do tworzenia rodziny, domu. [...] mieszkam $\mathrm{z}$ rodzicami. Rodzice trochę mnie tak chronią, bo to wiadomo, jak jest dziecko niepełnosprawne, to bardziej się na nim skupia, takie oczko w głowie, ale też bardzo prą mnie do przodu, bo teraz np. zrobiłam prawo jazdy, np. będę kupowała samochód, żeby się bardziej usamodzielnić" (Katarzyna).

„Kiedy patrzę na ludzi dorosłych, to nie widzę tego w sobie, co oni mają. Ja po prostu jeszcze jakby mi coś brakowało lub jakby... ja cały czas widzę w sobie po prostu taką ciekawość, ciekawość życia, ja po prostu cały czas czuję się elastyczny i dążę do tego, żeby po prostu mieć w swoim życiu przygody np. studia. [...] Jeśli chodzi o samą dorosłość, to nie czuję, że jestem zamknięty w jakiejś formie. Np. ludzie dorośli mają pewien zawód i ten zawód powoduje, że ludzie dorośli wiążą z nim pewną tożsamość i jest to pewnego rodzaju ograniczenie. Ja tego nie odczuwam w ten sposób, może dlatego, że jeszcze nie pracuję zawodowo" (Piotr).

Dorosłość ma także głębszy sens, bo jest traktowana jako umiejętność radzenia sobie z codziennością. Narrator użył tu określenia 
„wspinanie się po schodach”, określając dorosłość jako konsekwentne dążenie do przodu i pokonywanie trudności, aby móc iść dalej:

„Dorosłość to umiejętność radzenia sobie w codziennym życiu, ale jest to też podążanie za tym, to znaczy tą ścieżką jaką człowiek obrał, że po prostu konsekwentne dążenie za tym, w co uwierzyłem, co po prostu determinuje moje życie. [...] dorosłość to po prostu jakaś równowaga życiowa, powoli, bo powoli, staram się przeciwności pokonywać to jakby wspinanie się po schodach, jeśli coś osiągnąłeś, to idziemy dalej i dalej, aż do momentu, kiedy jakby te cechy które wypracowałeś, które składają się na twoją tożsamość, że ludzie postrzegają cię takm jak chcesz" (Piotr).

Rozmowy z badanymi uświadamiają nas, że w ich funkcjonowaniu nie mówi się o ograniczeniach. Oczywiście bariery są, ale nie determinują one życia badanych, przez co nadaje się ima małe znaczenie. Podejście narratorów do swojej niepełnosprawności i ograniczeń powoduje, że osoby te mają życiowe plany. Perspektywa przyszłości kształtuje ich teraźniejszość. Zaznaczyć jednak należy, że mimo pozytywnego nastawienia badanych osób do życia, siebie i ludzi, ich bycie w jakimś zakresie jest podyktowane niepełnosprawnością. Skutkuje to tym, że np. ewentualna praca musi być zgodna z ograniczeniami i mocnymi stronami wynikającymi z niepełnosprawności. Wszyscy rozmówcy studiują po to, aby zdobyć kwalifikacje niezbędne do podjęcia pracy. Studia te jednak zostały wybrane z perspektywy predyspozycji indywidualnych, jak również podyktowane niepełnosprawnością badanych:

„Chciałabym po pierwsze tak pójść dalej na studia magisterskie Terapia pedagogiczna, bo czuję, że jest to kierunek odpowiadający mojej niepełnosprawności i że będę mogła wykonywać taką pracę, to znaczy, że nie będzie przeszkodą to, że teraz nie chodzę" (Anna). 
„Przyszłość widzę w zawodzie, który studiuję jako pedagog specjalny. Chciałabym pracować w jakimś ośrodku, placówce specjalnej. Bardzo mi się to podoba i jeździłam do różnych ośrodków rehabilitacyjnych, gdzie była tam praca z dziećmi i uważam, że jest naprawdę świetnie, bo można pomóc wielu dzieciom, które potrzebują tego kontaktu z ludźmi, które nie mają takiej sprawności i wiedzy" (Katarzyna).

„Wszystko co jest związane z tymi studiami, traktuję po prostu jako naprawdę dobry czas. Staram się go wykorzystać dla mojego rozwoju itd. [...], bo ja traktuje studia... jakby one są uzupełnieniem moich kwalifikacji, [...] Chciałbym być opiekunem na obozach [...]" (Piotr).

Przyszłość, mimo że uwarunkowana $\mathrm{w}$ dużej mierze przez niepełnosprawność, nie niesie niepokoju. Ogromną siłę i nadzieję, która pozwala wierzyć narratorom, że w każdej sytuacji sobie poradzą, dają najbliżsi. Rodzina odgrywa ważną rolę w przygotowaniu do dorosłości. „Zahartowanie” na różne sytuacje wynikające z niepełnosprawności powoduje, że przyszłość nie jawi się naszym rozmówcom jako stan zagrożenia:

"Moja rodzina bardzo mnie we wszystkim wspiera - i rodzice, i siostra. Dzięki ich wsparciu wiem, że dam radę, ale to nie jest tak, że zawsze było ładnie i super. Mieliśmy wiele ciężkich chwil, ale to, że daliśmy radę, przygotowało mnie na różne sytuacje. Mimo wielu niewiadomych, nie boję się, co będzie jutro i dalej" (Katarzyna).

"Moja mama walczyła o to, żebym był w klasie i żeby ludzie $\mathrm{z}$ klasy też jakby hartowali mnie w tym, że świat jest światem, a ja jestem osobą niepełnosprawną. To nie jest tak, że ja jako osoba niepełnosprawna sprowadzam świat do siebie, tylko jakby mogę po prostu ćwiczyć się $\mathrm{w}$ tym, że mam wpływ na otaczające mnie środowisko i po prostu z każdą osobą, z którą się spotkałem, jakoś wpłynęliśmy na siebie wzajemnie i to też dało mi taką możliwość hartowania się" (Piotr). 


\section{Zakończenie}

Niepełnosprawność ma wiele twarzy. Ludzie nią dotknięci prezentują heterogeniczne postawy, wyznają różne wartości, niejednolicie interpretują ograniczenia $\mathrm{z}$ niej wynikające i nadają im różnorodne znaczenia. Wydawać by się mogło, że „inność” to kategoria nadrzędna w ich funkcjonowaniu. Nic bardziej mylnego. Analiza narracji ukazuje młodych niepełnosprawnych fizycznie studentów, którzy akceptują swoją niepełnosprawność i godzą się na implikacje z niej wynikające. Charakteryzują się pozytywnym nastawieniem do świata i ludzi oraz większą tolerancją na zachowania osób pełnosprawnych. Prezentowane przez nich postawy skutkują brakiem zgody $\mathrm{z}$ ich strony na funkcjonowanie stereotypów na temat niepełnosprawnych w ogóle, a szczególnie niepełnosprawnych fizycznie. Narratorzy, opowiadając swoje historie, nadają temu wielkie znaczenie, ponieważ doświadczając niepełnosprawności, sami są doskonałym przykładem na to, że stereotypy tracą na swojej wartości. W codziennym funkcjonowaniu przełamują mnóstwo poglądów, które ich zdaniem są krzywdzące, bo nieprawdziwe.

W doświadczeniach naszych rozmówców oprócz stereotypów pojawiły się także bariery. Narratorzy podkreślają fakt występowania barier architektonicznych i mentalnościowych. Bariery $\mathrm{w}$ ich odczuciu nie stanowią większego problemu, tak więc nasi rozmówcy nadają im małe znaczenie i interpretują fakt ich występowania jako codzienną trudność, z którą sobie radzą. W przypadku ograniczeń architektonicznych wykorzystują swoje doświadczenie jako osoby niepełnosprawne lub po prostu proszą o pomoc. Całkowita akceptacja swojej niepełnosprawności powoduje, że poczucie wartości naszych rozmówców nie jest zachwiane, co powoduje, że łatwiej im pokonywać bariery wynikające z postaw czy przekonań ludzi pełnosprawnych. Są otwarci na nowe znajomości i relacje, pierwsi wychodzą do osób pełnosprawnych i nie mają poczucia odrzucenia.

Pozytywne nastawienie do otaczającej rzeczywistości i jej realna ocena powodują, że nasi rozmówcy interpretują dorosłość bardzo 
naturalnie, a więc tak, jak ich pełnosprawni rówieśnicy. Utożsamiają ten etap życia z ukończeniem studiów, podjęciem pracy, założeniem rodziny. Duże znaczenie w konstruowaniu swojej dorosłości nadają samodzielności, dojrzałości i niezależności w podejmowaniu decyzji. Definiując własną dojrzałość, podkreślają znaczenie umiejętności radzenia sobie z codziennością. To przygotowanie jest dla naszych narratorów bardzo istotne, ponieważ daje siłę i motywację, aby „wspinać się po schodach”, czyli konsekwentnie dążyć do przodu i pokonywać trudności dnia codziennego wynikające z niepełnosprawności i z otoczenia społecznego.

Rozmowy z naszymi rozmówcami odsłaniają nowe oblicze niepełnosprawności fizycznej i ludzi nią dotkniętych. Następuje łamanie stereotypów, które ograniczały osoby niepełnosprawne fizycznie i nie pozwalały im realizować się $\mathrm{w}$ różnych płaszczyznach funkcjonowania społecznego. Definiowanie niepełnosprawności, jak też duża otwartość na codzienność i człowieka pełnosprawnego powoduje, że nasi rozmówcy żyją "normalnym” życiem. Oznacza, to, że studiują, mają znajomych i przyjaciól, marzą o pracy i założeniu rodziny. Ich plany na przyszłość nie różnią się od planów innych studentów. Wynika to być może $\mathrm{z}$ przygotowania przez rodziców do dorosłości i do życia wśród osób pełnosprawnych lub z innego, bardziej "łagodnego" podejścia otoczenia społecznego do niepełnosprawności fizycznej. „Zahartowanie” na różne sytuacje wynikające z niepełnosprawności powoduje, że przyszłość nie jawi się narratorom jako stan zagrożenia, ale jako realizacja życiowych planów i marzeń.

Wyniki z przeprowadzonych badań nie są uniwersalne. Te uogólnienia mają charakter prawd lokalnych i są nacechowane subiektywizmem naszym i naszych badanych. Odsłaniają jednak fragment "prawdy" na temat dorosłości konstruowanej przez młodych ludzi z niepełnosprawnością fizyczną wkraczających w dorosłość. Poznanie doświadczenia naszych rozmówców i tego, $\mathrm{w}$ jaki sposób opowiadają o tym doświadczeniu, jest kluczem do rozumienia i interpretowania ich postaw i zachowan. 


\section{Bibliografia}

Bauman Z., Ponowoczesność jako źródło cierpień, Wydawnictwo Sic!, Warszawa 2009.

Bauman Z., Wieloznaczność nowoczesna, nowoczesność wieloznaczna, Wydawnictwo Naukowe PWN, Warszawa 1995.

Chrzanowska I., Pedagogika specjalna. Od tradycji do wspótczesności, Wydawnictwo Impuls, Kraków 2015.

Cytowska B., Trudne drogi adaptacji. Watki emancypacyjne w analizie sytuacji dorostych osób z niepetnosprawnością intelektualna we wspótczesnym społeczeństwie polskim, Oficyna Wydawnicza „Impuls”, Kraków 2012.

Czykwin E., Stygmat społeczny, Wydawnictwo PWN, Warszawa 2008.

Goffman E., Piętno. Rozważania o zranionej tożsamości, Gdańskie Wydawnictwo Pedagogiczne, Gdańsk 2007.

Klus-Stańska D., Narracja w badaniu i kształceniu nauczycieli, „Forum Oświatowe” 2002.

Krause A., Człowiek niepetnosprawny wobec przeobrażeń społecznych, Oficyna Wydawnicza „Impuls”, Kraków 2004.

Ostrowska A., Niepetnosprawni w społeczeństwie 1993-2013, IFiS PAN, Warszawa 2015.

Rzedzicka K., Inny w edukacji, [w:] Dylematy pedagogiki specjalnej, red. A. Rakowska, J. Baran, Wydawnictwo Naukowe Akademii Pedagogicznej, Kraków 2000.

Rzeźnicka-Krupa J., Niepetnosprawność i świat społeczny. Szkice metodologiczne, Oficyna Wydawnicza „Impuls”, Kraków 2011.

Wojciechowski F., Stereotypy $i$ uprzedzenia a proces normalizacji życia osób z niepetnosprawnościa, [w:] Konteksty teoretyczne, red. E. Górniewicz, A. Krause, Wydawnictwo Uniwersytetu Warmińsko-Mazurskiego, Olsztyn 2003.

Woynarowska A., Niepetnosprawność intelektualna w publicznym i prywatnym dyskursie, Oficyna Wydawnicza „Impuls”, Kraków 2010.

Zakrzewska-Manterys E., Dziecko upośledzone - nieuchronność stereotypów, [w:] Niepetnosprawność intelektualna a style życia, red. A. Gustavsson, J. Tøssebro, E. Zakrzewska-Manterys, Wydawnictwo PAN, Warszawa 2003. 